\title{
The Determinants of Audit Quality: A Study Using the Approach of Earnings Surprise Benchmark
}

\author{
Reni Yendrawati ${ }^{1}$, Arifin Praditya Putra ${ }^{1} \&$ Rina Asmara ${ }^{2}$ \\ ${ }^{1}$ Universitas Islam Indonesia, Yogyakarta, Indonesia \\ ${ }^{2}$ Universitas Mercu Buana, Jakarta \\ Correspondence: Fakultas Bisnis dan Ekonomika, COndong Catur, Depok, Sleman. Kode pos: 55283 Indonesia. \\ Tel: 0274-881-546. E-mail: fe@uii.ac.id
}

Received: September 17, 2021; Accepted: October 4, 2021; Published: October 9, 2021

The research is financed by Universitas Islam Indonesia.

\begin{abstract}
This study aims to find empirical evidence regarding the influence of audit tenure, audit firm rotation, audit firm industry specialization, and time budget pressure on audit quality. This research is a quantitative research using secondary data in the form of financial statements. This study uses a population of manufacturing companies in the consumer goods sector listed on the Indonesia Stock Exchange in 2015-2017. The sampling was done by using a non-probability method with a purposive sampling technique. The number of samples used in this study is 34 companies. The data analysis method used is a logistic regression analysis method using Statistical Package for Social Sciences (SPSS) version 21. The results of this study indicate that audit tenure and audit firm rotation have no effect on audit quality, PAF industry specialization has a positive effect on audit quality, time budget pressure has a negative effect on audit quality.
\end{abstract}

Keywords: Audit Firm Rotation, Industry Specialization, Audit Tenure, Time Budget Pressure, and Audit Quality

\section{Introduction}

\subsection{Introduce the Problem}

It is well-known that financial statements serve as a tool for investors and stakeholders to know a company's condition. Nevertheless, the interest disparity between management and users of financial statements may lead to the unreliability of financial statements. That is why an audit by an independent auditor is of great importance. Independent auditor's opinion is an objective opinion on the company's financial statements so that the quality of audits conducted by independent auditors largely determines the quality of the information presented by company management.

An audit with good quality will more likely boost the reliability of financial statements, so that investors are able to make the right decisions on the information obtained from the financial statements. This is in line with the definition of audit quality by De Angelo (1981) in Watkins et al (2004) "The quality of audit services is defined to be the market-assessed joint probability that a given auditor will both (a) discover a breach in the client's accounting system, and (b) report the breach".

In relation to the research object, consumer goods companies are the object in this current research study. The varied level of financial risk and complex information of financial statements are the major reasons for choosing manufacturing companies as the research object. There are a few diverse research findings or research gaps that give rise to this current study.

Research by Mgbame \& Osazuwa (2012) on audit tenure found that audit tenure has a negative significant influence on audit quality. This finding is in line with Fitriany, Utama, Martani, \& Rosietta, (2015) and Prasetia \& Rozali, (2016). However, there is similar research regarding audit tenure on audit quality that revealed different findings. Rahmina \& Agoes, (2014) found that audit tenure and audit quality have a positive significant relationship.

In relation to PAF (Public Accounting Firms), Prasetia \& Rozali, (2016) revealed that the more frequent a company conducts audit firm rotation, it will lead to the decreased audit quality. To put it another way, the long-term 
relationship between the auditee and auditor has a negative significant effect on audit quality. This research finding is aligned with that of Suciana \& Setiawan (2018). According to Salsabila (2018), audit quality will rise if a company frequently rotates its audit firm. Similar findings were also found by Nadia (2015) and Fitriany, Utama, Martani, \& Rosietta (2015) that audit firm rotation has a positive significant effect on audit quality.

Studies by Suciana \& Setiawan (2018), Fitriany, Utama, Martani, \& Rosietta, (2015) showed that audit firm industry specialization positively and significantly influences audit quality. Butar-Butar \& Lily Indarto (2018) conducted similar research but found different results, that audit firm industry specialization has a negative and significant effect on audit quality.

Regarding time budget pressure, its effect on audit quality is necessary to examine as it has a positive and negative effect. In this case, the appropriate use of time will make the auditor try to complete his work effectively. A few studies have been conducted related to the topic. Arisinta (2013) explained that time budget pressure will affect the auditor when starting to make decisions or carry out an audit procedure. On the other hand, a client company that provides time budget pressure will be charged a lower cost. The sooner the working time of an audit, the lower the cost spent.

This research study serves to develop the research by Prasetia \& Rozali (2016) investigating audit tenure, audit firm rotation, and audit firm reputation on audit quality. What makes this current study differ from the study by Prasetia \& Rozali (2016) is the variable of audit firm industry specialization and time budget pressure are the new variables to be investigated, and the variable of audit firm reputation is omitted.

\subsection{Audit Quality}

Audit quality is a probability of an auditor to discover and report frauds in his/her client's accounting system. To produce a good audit quality, an audit conducted must be based on the Professional Standard of Public Accountant determined by the Indonesian Institute of Public Accountant (IAPI). The principles and responsibilities of IAPI as an accounting standard are to conduct assessments and responses to the risks, on audit evidences and use of other parties' works, conclusions and audit reporting, and specific areas (Panduan Indikator Kualitas Audit Pada Kantor Akuntan Publik, 2016).

According to SA 220 (2013), a good audit quality has a few requirements. The audit fits the professional standards and the government regulations. It has a standardized audit firm as quality control. The audit reports issued are consistent with the existing conditions. In addition, the auditor has to be brave to report a material misrepresentation without fear. These indicators are of great essence in carrying out audit engagement.

\subsection{Agency Theory}

Agency theory describes the relationship between owners and managers. Fitriany, Utama, Martani, \& Rosietta (2015) explained that agency theory serves as a contractual relation between the company owner or principal and the manager or agent. The contract contains some information stating that the agent must perform in accordance with the principal's authority. In fact, the agent and principal have different interests and may likely lead to a conflict of interest between the two. Such conditions can cause asymmetric information between the agent and principal. For example, the agent tends to present financial statements showing good performance. Thus, examining the financial statements is essential to get the assurance of whether the financial statements is free from material misstatement. The examination of financial statements is termed as an audit. Having audits through an objective and systematic audit process is one of the ways to resolve the problems because the auditor position as the independent party makes the auditor reports more reliable.

\subsection{Audit Tenure}

Audit tenure is terms of engagement between audit firms and client corporations. In Indonesia, the audit tenure is regulated in the governmental regulation No. 20/2015 on the practice of public accounting. It is stated in the regulation that the audit tenure is five consecutive years. The public accountant is allowed again to provide audit services after two consecutive years of not providing audit services. The engagement term of the audit firm is not restricted.

The audit tenure between auditor and client will affect the independence level of the auditor. It means the decreased auditor independence will more likely affect the auditor objectivity when assessing the client corporation. As the objectivity is reduced, it will lead to the failure of detecting material misstatement in the financial statements. Consequently, it will lower the auditor's judgment quality. 


\subsection{Rotation of Audit Firms}

Another factor that affects audit quality is audit firm rotation. It is the decision made by the management to change the audit firm. According to Suciana (2018), changing auditor can be carried out by being subject to (mandatory) or without being subject (voluntary) to the provisions by the government. Indonesian Government through the decree of finance minister No. 17 / PMK.01 / 2008, requires corporations to change the audit firm who has performed auditing for 6 consecutive years and performed an audit change for 3 consecutive years. Rotation requirements are based on the theoretical reasons that the implementation of rotation and audit firms is expected to enhance auditor independence.

In corporations, an independent auditor serves as a mediator between the manager and the owner who have different interests. An independent auditor also functions to reduce costs - the costs due to frauds committed by the management. Thus, to maintain auditor independence, the government regulates mandatory auditor rotation.

Siregar, Amarullah, Wibowo, \& Anggraita, (2012) stated that auditor rotation rule aims to increase audit quality. In other words, long-term auditor client relationship will more likely decrease auditor independence. On the other side, the rotation will lower audit quality, as it takes a longer time for an auditor to know a company to be audited.

\subsection{Industry Specialization}

Industry specialization is the specialty that an auditor owns to carry out an audit process in a corporation industry. When doing an audit process, the auditor must understand the client's business in order to be able to identify all events that occur in the client's business. The more frequent the same industry is handled by the auditor, it will make the auditor have more experience in the industry. Then, it will increase the auditor's knowledge and understanding of audit risks, business risks, and the company's internal control in the industry. The specialty in a certain industry will affect knowledge and the ability to carry out an audit process. Otherwise, the auditor without a certain specialty tends to own lower ability and knowledge. Fitriany, Utama, Martani, \& Rosietta, (2015) in their research found that the specialist auditor has more experiences in auditing companies from the same industry. Consequently, the more experience the auditor has, it will enhance the auditor's understanding of audit risks specifically related to the industry.

\subsection{Time Budget Pressure}

Time Budget Pressure is a condition when an auditor is required to manage the agreed time budget efficiently or there has been a rigid discussion regarding audit time budget (Nirmala \& Cahyonowati, 2013). An auditor's work is time-restricted, hence an audit firm needs to create a time budget in each audit activity. However, audit time budget often does not suit the execution. Audit time budget simply makes an auditor work under pressure to complete the tasks according to the budgeted time. When faced with a time budget, there are two possible responses by the auditor - functional and dysfunctional. The former is the behavior in which an auditor uses the budgeted time well so as to yield good audit quality, while the latter is the actions by the auditor in carrying out tasks that will likely make the audit quality reduced (Arisinta, 2013).

\subsection{Hypotesis Formulation}

Longer engagement between auditor and client will likely lead to decreased auditor independence, which in turn lower the auditor's objectivity in assessing the client. Consequently, the auditor will tend to side with the client management due to longer engagement and more frequent meetings. Thus, audit tenure has a negative effect on audit quality. Studies of audit tenure by Mgbame \& Osazuwa (2012) found that the influence of audit tenure on audit quality has a significant and negative relationship. This finding is in line with the findings by Fitriany, Utama, Martani, \& Rosietta, (2015) and Prasetia \& Rozali, (2016). Hypothesis 1 is then proposed as follows: H1 : Audit tenure has a negative effect on audit quality.

Audit firm rotation will have a positive effect on audit quality. The more frequent a corporation changes its audit firm, it will lead to better audit quality. In this case, a higher frequency of audit firm changes will boost investors' and stakeholders' confidence because they consider that changed auditor will have higher independence and have better assessment quality. According to Salsabila (2018), the more frequent a corporation alters its audit firm, the better the audit quality. In other words, audit firm rotation will have a significant and positive effect on audit quality. This finding is aligned with the studies by Nadia (2015) and Fitriany, Utama, Martani, \& Rosietta, (2015). Hypothesis 2 is then proposed as follows: $\mathrm{H} 2$ : Audit firm rotation has a positive effect on audit quality.

When an audit firm frequently deals with the same industry, it makes the audit firm have more experience in the industry. Consequently, it will increase more knowledge and understanding of audit risks, business risks and a company's internal controls in the industry. Thus, a particular industry specialization has an effect on knowledge and the ability to carry out an audit process. The study by Suciana \& Setiawan (2018) revealed that industry 
specialization has a positive and significant effect on audit quality. This finding corroborates the research finding by Fitriany, Utama, Martani, \& Rosietta, (2015). Hypothesis 3 is then proposed as follows: H3: Industry Specialization of the audit firm has a positive effect on audit quality.

The pressure in the form of time budget provided to the auditor to complete tasks will affect the audit quality. The auditor is inclined to work less prudently or put much trust on the client's presentation which in turn leads to less accurate audit results. The less accurate results will lower the audit quality. Nirmala \& Cahyonowati (2013) in their research found that the higher the time budget pressure faced by the auditor, it will likely trigger dysfunctional behavior which in turn results in reduced audit quality. Hypothesis 4 is then proposed as follows: H4: Time Budget Pressure has a negative effect on audit quality

\section{Method}

\subsection{Population and Sample}

The research population is manufacturing companies in the consumer goods sector listed on the Indonesian Stock Exchange during 2015 - 2017. The sampling method used is purposive sampling. According to Sugiyono (2015), "purposive sampling is a sampling technique with particular considerations". There are a few criteria for the sampling technique in this current research study. The companies to be investigated are manufacturing companies in the consumer goods sector listed on the Indonesian Stock Exchange (IDX) from 2015 to 2017. The manufacturing companies in the consumer goods sector that are not delisted from the IDX. The manufacturing companies in the consumer goods sector whose financial statements have been audited by independent auditors, published their annual reports and provided the information needed in this research during the period 2015-2017.

\subsection{Kinds and Data Source}

This research study makes use of secondary data. Secondary data is the data gathered from the documents associated with the investigated object. The entire data in this current research comprise quantitative and qualitative data expressed in numerical form. The data include the annual reports and financial statements of the manufacturing companies in the consumer goods sector listed on the IDX during 2015 - 2017 as well as a few literatures associated with this study. The companies' annual reports and financial statements are taken from the web www.idx.co.id.

\subsection{Data Collection Method}

Documenting method is the method used in gathering the data in this research. It is done by collecting, recording, studying the documents and the secondary data in the form of financial statements that have been audited by external auditors. The research review is done by acquiring prior studies and other literature, while the theoretical review is done by gathering information from books, accounting journals, articles, laws, and other sources related to the research.

\subsection{Definitions and Variable Measurement}

\subsubsection{Dependent Variable}

According to Sugiyono (2015), "dependent variable or bound variable is the variable that is affected or becomes the effect due to free variables". The dependent variable in this study is audit quality. Audit quality (Y) can be defined as the likelihood of the auditor to discover and report material misstatement in an audit report in accordance with the criteria. In this research study, earnings surprise benchmark is the proxy of audit quality (Suciana \& Setiawan, 2018), in that it is to detect and reveal the profit management aiming to avoid loss reporting. According to Suciana \& Setiawan (2018), audit quality is categorized into two:

a. High audit quality (MEET_BE=1) when the profit value is in the range of normal value.

b. Low audit quality (MEET_BE $=0$ ) when the profit value is out of the range of normal value. The assumption of audit quality is low, if:

i. The profit exceeds earning benchmark, that is the value of $\mathrm{ROA}>\mu+\sigma$

ii. The loss exceeds earning benchmark, that is the value of $\mathrm{ROA}<\mu+\sigma$

ROA formula is used to measure audit quality, by checking out whether the ROA is in the benchmark. If the ROA is in the benchmark $(\mu-\sigma<\mathrm{ROA}<\mu+\sigma)$, it signifies good audit quality. Otherwise, if the ROA is out of the benchmark $(\operatorname{ROA}>\mu+\sigma)$ or $(\mathrm{ROA}<\mu+\sigma)$, it signifies poor audit quality. $\mu$ is the average ROA from the entire sample companies and $\sigma$ it is its deviation. It means when an audit firm can provide better audit quality, the client will put more trust on its services. Good audit quality is given a score of 1 , while poor audit quality is given a score of 0 . This variable is symbolized by AQ. 


\subsubsection{Independent Variables}

Audit Tenure

Audit tenure is terms of audit engagement between an audit firm and an entity to provide opinions on financial statements of the client. Audit tenure is measured by the amount of engagement years in which the auditor from the same audit firm conducts an audit engagement with one client; the first year of the engagement starts from number 1 added with one for subsequent years. AT symbolizes this variable.

\section{Audit Firm Rotation}

Rotation is an accountant changing both public accountants and audit firms by a company. In Indonesia, it is mandatory that the changing of public accountants is done after 3 consecutive years and audit firms after six consecutive years. The assessment of public accountants and audit firms rotation uses dummy variable in this research. If a company being investigated conducts public accountant rotation, a score of 1 is given; while not performing public accountant rotation, a score of 0 is given. Audit firm rotation also makes use of dummy variable. If a company being investigated performs audit firm rotation, a score of 1 is given; while not performing audit firm rotation, a score of 0 is given. AFR. symbolizes this variable

\section{Audit Firm's Industry Specialization}

Auditor specialization in a certain industry makes the auditor have adequate ability and knowledge compared with those without specialization. The variable of industry specialization refers to Nizar (2017) that the value of specialist auditor is proxied by using a formula of auditor industry specialization. A score of 1 is given for a specialist auditor and 0 for a non-specialist auditor. The audit firm is considered industry specialization if it has audited $15 \%$ or more emitents in the same industry. The percentage of auditor industry specialization (AIS) is calculated as follows:

$$
A I S=\frac{\text { the amount of clients in the industry } Y}{\text { the amount of emitents in the industry } Y} \times 100 \%
$$

\section{Time Budget Pressure}

Time Budget Pressure is the time budget provided to the auditor to audit a company, so the auditor is required to manage the budgeted time in an efficient way. Time budget pressure will make the auditor work under pressure because the tasks must be completed according to the agreed time allocation. This variable refers to Nugroho (2018) that the value of specialist auditor is proxied by using the following formula:

\section{Time Budget Pressure $=$ Audit Report Date - Financial Statement Date}

\subsection{Data Analysis Technique}

This research study employs logistic regression to test the hypotheses. According to Ghozali (2016:321), logistic analysis is the regression to test whether the bound variable can be predicted by its free variables. In this case, logistic regression analysis does not need data normality (classical assumption) on the free variables. The logistic regression equation is formulated as follows:

$$
\begin{gathered}
\mathbf{A Q}=\boldsymbol{\alpha}+\boldsymbol{\beta 1} \mathbf{A T}+\boldsymbol{\beta 2} \mathbf{A F R}+\boldsymbol{\beta 3} \text { IS }+\boldsymbol{\beta 3} \mathbf{T B P}+\boldsymbol{\varepsilon} \\
\text { Information: } \alpha \quad=\text { Constanta } \\
\mathrm{AT}=\text { Audit Tenure } \\
\mathrm{AFR}=\text { Audit Firm Rotation } \\
\mathrm{IS}=\text { Industry Specialization } \\
\mathrm{TBP}=\text { Time Budget Pressure } \\
\mathrm{AQ}=\text { Audit Quality } \\
\varepsilon=\text { Error (residual) }
\end{gathered}
$$

The steps to conducting logistic regression test are as follows (Ghozali, 2016): Assessing Fit Model (overall fit model), Coefficient of Determination (R2), Testing Regression Model Fit, and Hypothesis Testing (Wald Test). 


\section{Results}

\subsection{Descriptive Statistic Analysis}

Test of descriptive statistics is conducted by comparing minimum value, maximum value, and sample average. This analysis is used to describe the data. In this research, the analysis is seen using minimum value, maximum value, average and deviation standard. The results of descriptive statistic analysis can be viewed in table 1 below:

Table 1. Results of Descriptive Statistic Analysis

\begin{tabular}{llllll}
\hline Variable & $\mathrm{N}$ & Minimum & Maximum & Mean & Std. Deviation \\
\hline Audit Quality & 102 & 0 & 1 & .73 & .448 \\
Audit Tenure & 102 & 1 & 3 & 1.53 & .685 \\
Audit Firm Rotation & 102 & 0 & 1 & .31 & .466 \\
Industry Specialization & 102 & 0 & 1 & .23 & .420 \\
Time Budget Pressure & 102 & 50 & 180 & 81.75 & 22,122 \\
Valid n & 102 & & & & \\
\hline
\end{tabular}

\subsection{Results of Model Analysis}

\subsubsection{Assessing Model Fit and Overall Model (Overall Model Fit)}

This test aims to assess whether the model being hypothesized fits the data. It is done by the following hypotheses:

H0: The model being hypothesized fits the data

Ha: The model being hypothesized does not fit the data

This testing is conducted by comparing the values between initial 2Log Likelihood (block number $=0$ ) and the value of final $-2 \log$ Likelihood (block number $=1$ ). The value of initial $-2 \log$ Likelihood at the block number $=$ 0 is shown in the table below:

Table 2. Likelihood Block 0

\begin{tabular}{llll}
\hline Iteration & -2 Log likelihood & Coefficients \\
\cline { 3 - 3 } & & & Constant \\
\hline \multirow{3}{*}{ Step 0 } & 1 & 119,990 & .902 \\
& 2 & 119,889 & .971 \\
& 3 & 119,889 & .972 \\
\hline
\end{tabular}

Table 3. Likelihood Block 1

\begin{tabular}{cllllll}
\hline Iteration & $\begin{array}{l}-2 \quad \text { Log } \\
\text { likelihood }\end{array}$ & $\begin{array}{l}\text { Coefficients } \\
\text { Constant }\end{array}$ & $\begin{array}{l}\text { Audit } \\
\text { Tenure }\end{array}$ & $\begin{array}{l}\text { Audit } \\
\text { Firm } \\
\text { Rotation }\end{array}$ & $\begin{array}{l}\text { Industry } \\
\text { Specialization }\end{array}$ & Time_Budget_Pressure \\
\hline 1 & 106,844 & 8,955 & -.341 & -.322 & 1,392 & $-1,853$ \\
2 & 104,473 & 10,517 & -.535 & -.482 & 2,367 & $-2,173$ \\
3 & 104,214 & 10,667 & -.586 & -.516 & 2,879 & $-2,201$ \\
4 & 104,206 & 10,673 & -.589 & -.518 & 2,990 & $-2,202$ \\
5 & 104,206 & 10,673 & -.589 & -.518 & 2,995 & $-2,203$ \\
6 & 104,206 & 10,673 & -.589 & -.518 & 2,995 & $-2,203$ \\
\hline
\end{tabular}

Tables 2 and 3 display the results of testing conducted by comparing the values between initial -2 Log Likelihood (-2LL) (Block Number=0) and final -2 Log Likelihood (-2LL) (Block Number=1). The value of -2LL is 119,990. Having inserted two independent variables, the value of final -2LL has declined to be 104,206. This decline shows a better regression model or, in other words, the model being hypothesized fits the data.

The first step to do is to assess the fit of regression model. A model is considered able to predict an observation value as it fits the observation data, when the value of Hosmer and Lemeshow Goodness of fit test $>0.05$. Tables 
4 and 5 demonstrate the statistical value of Hosmer and Lemeshow Goodness of fit test which is 5.908 with the significance probability value of 0.658 , above 0.05 .

Table 4. Results of Hosmer and Lemeshow Test

\begin{tabular}{llll}
\hline Step & Chi-square & Df & Sig. \\
\hline 1 & 5.908 & 8 & .658 \\
\hline
\end{tabular}

Based on the analysis, it can be concluded that the regression model is feasible for use in further analysis, as there is no obvious difference between the predicted and the observed clarifications.

\subsubsection{Analysis of Binary Logistic Regression Coefficient}

Hypothesis testing in this study is aimed at examining the influence of independent variables - audit tenure, audit firm rotation, industry specialization and time budget pressure on audit quality. When the significance level is < 0.05 , the hypothesis is accepted.

Table 5. Variables in the Equation

\begin{tabular}{lllllll}
\hline & B & S.E. & Wald & df & Sig. & Exp(B) \\
\hline Audit Tenure & -.589 & .789 & .558 & 1 & .455 & .555 \\
Audit Firm Rotation & -.518 & .786 & .435 & 1 & .510 & .596 \\
Industry Specialization & 2.995 & 1.372 & 4.764 & 1 & .029 & 19.987 \\
Time_Budget_Pressure & -2.203 & 1.037 & 4.513 & 1 & .034 & .111 \\
Constant & 10.673 & 4.633 & 5.308 & 1 & .021 & 43190.150 \\
\hline
\end{tabular}

From the equation of the logistic regression, a model of logistic regression is obtained as follows:

$\mathrm{KA}=10.673-0.589 \mathrm{TA}-0.518 \mathrm{RA}+2.995 \mathrm{SIK}-2.203 \mathrm{TBP}$

Based on the table above, it can be explained as follows: Audit tenure has a significance level of 0.455 , larger than a significance level of 0.05 so that this variable does have a significant effect on audit quality. Audit firm rotation has a significance level of 0.510 , larger than a significance level of 0.05 so that this variable does not have a significant effect on audit quality. Industry specialization has a significance level of 0.029 , smaller than a significance level of 0.05 so that this variable has a significant effect on audit quality. Time Budget Pressure has a significance level of 0.034 , smaller than a significance level of 0.05 so that this variable has a significant effect on audit quality.

\subsubsection{Results of Determination Coefficient Test (Nagelkerke R2)}

Nagelkerke R Square is a modification of Cox and Snell's coefficient to ensure that the values vary from 0 to 1 . It is done by dividing the value of Cox and Snell's R2 with its maximum value. The value of Nagelkerke R2 can be interpreted as the value of R2 on multiple regression. The results of Nagelkerke can be seen in table 6 .

Table 6. Nagelkerke R Square

\begin{tabular}{llll}
\hline Step & -2 Log likelihood & Cox \& Snell R Square & Nagelkerke R Square \\
\hline 1 & $104.206^{\mathrm{a}}$ & .143 & .206 \\
\hline
\end{tabular}

Table 6 demonstrates that the value of Nagelkerke R Square is 0.206 . It means that the variability of the dependent variable that can be explained by the variability of the independent variables is $20.6 \%$, while the rest $(79.4 \%)$ is explained by other variables excluded in this research study.

\subsubsection{Results of Partial Test (Wald Test)}

The statistical test of Wald from the results of logistic regression aims to discover the influence of each independent variable on the dependent variable. Logistic regression coefficient can be determined by using p-value (probability value), that is comparing the p-value and $\alpha$. The decision making in this testing is the significance level $(\alpha)$ is $5 \%$ and the criteria of hypothesis testing are based on the significance. If the $\mathrm{p}$ is larger than a significance level of 5\% (sig-p >0.05), it can be concluded that there is no influence between the independent and dependent variables, and 
the regression coefficient matches the predicted one. In contrast, if the $\mathrm{p}$ is smaller than a significance level of 5\% (sig-p <0.05), that means there is an influence between the independent and dependent variables, so the hypothesis is accepted. The results of hypothesis testing can be seen in table 7 .

Table 7. Recapitulation of Hypothesis

\begin{tabular}{lllll}
\hline Hypothesis & Information & B & Sign. & Conclusions \\
\hline 1 & Audit tenure has a negative influence on audit quality & -0.589 & 0.455 & not supported \\
2 & Audit firm rotation has a positive influence on audit quality & -0.518 & 0.510 & not supported \\
3 & Industry specialization has a positive influence on audit quality & 2.995 & 0.029 & supported \\
4 & Time budget pressure has a negative influence on audit quality & -2.203 & 0.034 & supported \\
\hline
\end{tabular}

Hypothesis 1 states that audit tenure has a negative influence on audit quality. Testing on the first hypothesis is done through a test of significance regression coefficient from the audit tenure variable. The regression coefficient value of this variable is -0.589 with a significance value of 0.455 and on a significance level of $\alpha=5 \%$; hence the regression coefficient is significant as $0.455>0.05$. Thus, it can be concluded that audit tenure does not have a significant influence on audit quality. Ha 1 is not supported.

Hypothesis 2 states that audit firm rotation has a positive influence on audit quality. Testing on the second hypothesis is done through a test of significance regression coefficient from the variable audit firm rotation. The regression coefficient value of this variable is -0.518 with a significance value of 0.510 and on a significance level of $\alpha=5 \%$; hence the regression coefficient is not significant as $0.510>0.05$. Thus, audit firm rotation does not have a significant influence on audit quality. Ha 2 is not supported.

Hypothesis 3 states that industry specialization has a positive influence on audit quality. Testing on the third hypothesis is done through a test of significance regression coefficient from the variable industry specialization. The regression coefficient value of this variable is Nilai 2.995 with a significance value of 0.029 and on a significance level of $\alpha=5 \%$; hence the regression coefficient is significant as $0.029<0.05$. Thus, industry specialization has a positive influence on audit quality. Ha 3 is supported.

Hypothesis 4 states that time budget pressure has a significant negative influence on audit quality. Testing on this fourth hypothesis is done through a test of significance regression coefficient from the variable time budget pressure. The regression coefficient value of time budget pressure is -2.203 with a significance value of 0.034 and a significance level of $\alpha=5 \%$; hence the regression coefficient is significant as $0.034<0.05$. Thus, time budget pressure has a negative significant influence on audit quality. Ha 4 is supported.

\section{Discussion}

The research finding has revealed that audit tenure does not have a significant influence on audit quality. It indicates that longer engagement between auditor and client does not affect a company's audit quality. The first hypothesis is rejected because the length of the relationship between the auditor and the client does not become a benchmark that audit quality will decrease. The auditor seems to always try to maintain his/her good name and independence despite auditing a client for a long period of time as the auditor is required to work professionally. This finding is in line with Rahmina \& Agoes (2014) that audit tenure does not have a significant influence on audit quality.

Audit firm rotation does not have a significant influence on audit quality, which means that if a company performs audit firm rotation, it will not affect the company's audit quality. The second hypothesis is rejected because the companies just believed that using any audit firms, audit quality remains good. The ignorance is based on the belief that audit firms must be subject to a quality control system of audit firms and pay attention to the code of auditing ethics (Pradana \& Biswan, 2018). The companies assumed that audit firm rotation is not the benchmark to gain better audit quality. This finding is aligned with Hartadi (2012) who found that audit firm rotation does not have a significant influence on audit quality

Industry specialization has a positive and significant influence on audit quality. It indicates that using the audit firm with a certain industry specialization will enhance audit quality. It is well known that a specialist auditor has more experience in the client's industry, if compared with a non-specialist auditor, so that a specialist auditor is considered more reliable in producing good audit quality. This finding corroborates the finding by Suciana \& Setiawan (2018) that the companies audited by a specialist auditor will have much better audit quality, compared with non-specialist auditor. 
Time Budget Pressure has a negative significant influence on audit quality. This means time budget pressure will lower audit quality. In this case, an auditor will work less prudently, put much trust in the client's presentation, so that the audit results will be less accurate. This finding supports the finding by Nirmala \& Cahyonowati (2013) that the higher the time budget pressure faced by the auditor, the higher the likelihood of the emergence of dysfunctional behavior which causes reduced audit quality.

There are a few limitations in this research study, among others are: (1) This research study took the research sample from manufacturing companies in the consumer goods sector and the financial statements and annual reports being investigated are only in a period of 3 years. It is considered that the sample has not represented the corporations listed on the IDX. (2) There are only four independent variables used - audit tenure, audit firm rotation, industry specialization, and time budget pressure. Other variables allegedly affecting audit quality may be investigated in future studies.

Based on the limitations, there are few suggestions for future possible studies: (1) It is suggested that future studies extend more research periods in order to be able to generalize the research results. In addition, they can use more company samples, such as companies in manufacturing, banking, mining, telecommunication sectors, etc in order to be able to compare the audit quality in each sector or each kind of industry. (2) It is suggested that future studies add more other independent variables, for example, GCG mechanism and audit opinions.

This research study has a few implications. In relation to industry specialization positively affecting audit quality, companies are expected to hire auditors with specialization. This study has proven that the auditor with specialization will be able to easily detect frauds and errors in financial reporting. This is because the more experiences the auditor has, the more knowledge and better understanding she/he has in the field being audited.

\section{Acknowledgments}

Alhamdulillaahirobil'alamin, the researcher expresses his highest gratitude to Allah Subhanahu Wa Ta'ala for blessing, love, opportunity, health and mercy to complete this research. Thank you to the accounting department of the Indonesian Islamic University and Mercu Buana University who have supported this research.

\section{References}

Arens, A. A., S.Beasley, M., \& Randal, J. E. (2012). Auditing and Assurance Services: An Integrated Approach, 1.3., Pearson Prentice Hall.

Arisinta, O. (2013). Pengaruh Kompetensi , Independensi , Time Budget Pressure, Dan Audit Fee Terhadap Kualitas Audit Pada Kantor Akuntan Publik Di Surabaya. Journal Ekonomi Dan Bisnis, 3, 266-278.

Butar-Butar, S., \& Lily, I. S. L. I. (2018). Does Auditor Industry Expertise Improve Audit Quality In Complex Business Environments? Journal Akuntansi Dan Keuangan, 20(1), 1-12. https://doi.org/10.9744/jak.20.1.112

Fitriany, U. S., Martani, D., \& Rosietta, H. (2015). Pengaruh Tenure, Rotasi dan Spesialisasi Kantor Akuntan Publik (KAP) Terhadap Kualitas Audit: Perbandingan Sebelum dan Sesudah Regulasi Rotasi KAP di Indonesia. Journal Akuntansi Dan Keuangan, 17(1), 12-27. https://doi.org/10.9744/jak.17.1.12-27

Mgbame, C. O., \& Osazuwa, E. E. N. P. (2012). Audit Partner Tenure and Audit Quality: An Empirical Analysis Chijoke. Journal of Business Logistics, 15(1), 29.

Nadia, N. F. (2015). Pengaruh Tenur Kap, Reputasi Kap Dan Rotasi Kap Terhadap Kualitas Audit Nurul Fitri Nadia 2. Journal Akuntansi Bisnis, XIII(26), 113-130.

Nirmala, R. P. A., \& Cahyonowati, N. (2013). Professional Care, Akuntabilitas , Kompleksitas Audit, Dan Time Budget Pressure Terhadap Kualitas Audit. Journal of Accounting, 2(3), 1-12.

Nizar, A. A. (2017). Pengaruh Rotasi, Reputasi dan Spesialisasi Auditor Terhadap Kualitas Audit. Journal Ilmiah Akuntansi: Kompartemen, $X V(2), 157-172$.

Nugroho, L. (2018). Analisa Faktor-Faktor Yang Mempengaruhi Kualitas Audit. Journal Maneksi, 7(1), 55-65. https://doi.org/10.31959/jm.v7i1.89

Pradana, H. H., \& Biswan, A. T. (2018). Penerapan Sistem Pengendalian Mutu Kantor Akuntan Publik. Journal Substansi, 2(1), 39-58.

Prasetia, I. F., \& Rozali, R. D. Y. (2016). Pengaruh Tenur Audit, Rotasi Audit Dan Reputasi Kap Terhadap Kualitas Audit. Journal Aset (Akuntansi Riset), 8(1), 39-50. https://doi.org/10.17509/jaset.v8i1.4020

Rahmina, L. Y., \& Agoes, S. (2014). Influence of Auditor Independence, Audit Tenure, and Audit Fee on Audit 
Quality of Members of Capital Market Accountant Forum in Indonesia. Procedia - Social and Behavioral Sciences, 164, 324-331. https://doi.org/10.1016/j.sbspro.2014.11.083

Salsabila, M. (2018). Pengaruh Rotasi Kap Dan Fee Audit Terhadap Kualitas Audit Pada Perusahaan Sektor Keuangan Yang Terdaftar Di Bursa Efek Indonesia (BEI). Journal Riset Akuntansi \& Bisnis, 18(1), 51-66. https://doi.org/10.30596/jrab.v18i1.2050

Siregar, S. V., Amarullah, F., Wibowo, A., \& Anggraita, V. (2012). Audit tenure, auditor rotation, and audit quality: The case of Indonesia. Asian Journal of Business and Accounting, 5(1), 55-74.

Suciana, M. F., \& Setiawan, M. A. (2018). Pengaruh Rotasi Audit, Spesialisasi Industri KAP, dan Client Importance Terhadap Kualitas Audit ( Studi dengan Pendekatan Earning Surprise Benchmark ). Journal WRA, 6(1), 1159-1172. https://doi.org/10.24036/wra.v6i1.101939

Sugiyono. (2015), Metode Penelitian Pendidikan (Pendekatan Kuantitatif, Kualitatif Dan R\&D), CV. Alfabeta, Bandung.

Watkins, A. L., Hillison, W., \& Morecroft, S. E. (2004). Audit Quality: A Synthesis of Theory and Empirical Evidence. Journal of Accounting Literature, 33, 153-193.

\section{Copyrights}

Copyright for this article is retained by the author(s), with first publication rights granted to the journal.

This is an open-access article distributed under the terms and conditions of the Creative Commons Attribution license (http://creativecommons.org/licenses/by/4.0/). 